\title{
Macronutrient omission and the development and nutritional status of basil in nutritive solution
}

\section{Bernardo Melo Montes Nogueira Borges, Rilner Alves Flores, Hilário Júnior de Almeida, Leandro Rossato Moda \& Renato de Mello Prado}

To cite this article: Bernardo Melo Montes Nogueira Borges, Rilner Alves Flores, Hilário Júnior de Almeida, Leandro Rossato Moda \& Renato de Mello Prado (2016) Macronutrient omission and the development and nutritional status of basil in nutritive solution, Journal of Plant Nutrition, 39:11, 1627-1633, DOI: $10.1080 / 01904167.2016 .1187742$

To link to this article: https://doi.org/10.1080/01904167.2016.1187742

Accepted author version posted online: 10

Jun 2016.

Published online: 10 Jun 2016.

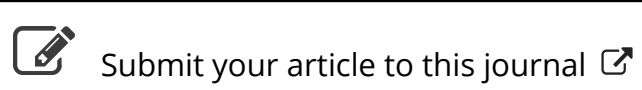

Џ Article views: 98

View Crossmark data ¿ 


\title{
Macronutrient omission and the development and nutritional status of basil in nutritive solution
}

\author{
Bernardo Melo Montes Nogueira Borges, Rilner Alves Flores, Hilário Júnior de Almeida, \\ Leandro Rossato Moda, and Renato de Mello Prado
}

Department of Soil Science, Faculdade de Ciências Agrárias e Veterinárias, UNESP - Univ Estadual Paulista, Jaboticabal, Brazil

\begin{abstract}
The correct nutrition of basil (Ocinum basilicum L.) is important to increase its production and quality; however, few papers have deal with this subject. The aim of this work was to evaluate the effects of omission of individual macronutrients on the growth and nutritional status of basil cultivated in nutritive solution. The treatments consisted of nutrient solutions with nitrogen, phosphorus, potassium, calcium, magnesium or sulfur $(\mathrm{N}, \mathrm{P}, \mathrm{K}, \mathrm{Ca}$, $\mathrm{Mg}$, or S) omissions and a complete solution treatment. The plants were cultivated in $8 \mathrm{~L}$ plant pots. Plant height, number of leaves per plant, leaf area, relative chlorophyll index, net photosynthesis rate, stomatal conductance, plant dry matter, concentration levels of macronutrients in the aerial part and root system, and nutritional disorders were all evaluated. Nutrient omission was a limiting factor for plant development, substantially reducing its growth. There was also a considerable decrease in nutrient accumulation when compared to the control treatment.
\end{abstract}

\section{ARTICLE HISTORY}

Received 3 April 2013

Accepted 14 July 2014

\section{KEYWORDS}

Ocinum basilicum; nutritional deficiency; mineral nutrition; symptomatology; yield

\section{Introduction}

Basil is an herbaceous plant, annual or perennial, with a well-branched stem, reaching approximately $0.6 \mathrm{~m}$ high, containing essential oils, tannin, flavonoids and saponins. A member of the Laminaceae family, genus Ocinum, it consists of approximately 30 species of herbs and sub-shrubs growing in tropical and temperate regions (Blank et al., 2004). The plant is an important source of essential oils, including medical applications among its uses, and is also rich in linalool, which when industrialized can be used as an antioxidant or flavoring as well as in the cosmetics industry (Pereira and Moreira, 2011).

Hydroponic cultivation can optimize yield with a higher number of harvests, especially for producing high value cultures of high quality and free of pesticides. However, it is important that is cultivated in a way that fully meets its nutritional requirement (Dzida, 2011), because nutritional deficiency affects vegetative development and photosynthetic capacity, which may in turn affect production (Araujo et al., 2011). In addition, an excessive increase in nutrients can lead to a higher yield but with a lower quality, decreasing the oil content and its qualities (Sharafzadeh et al., 2011).

Information about basil nutrition, including its nutritional demands, is scarce in the literature as well as the description of macronutrients deficiency symptomatology, according to what we were able to find. However, it is of concern when the objective is hydroponic production of quality basil (Blank et al., 2004).

CONTACT Bernardo Melo Montes Nogueira Borges bernardonog@hotmail.com Department of Soil Science, Faculdade de Ciências Agrárias e Veterinárias, UNESP - Univ Estadual Paulista, Jaboticabal, SP 14884-900, Brazil. 
The aim of this work was to evaluate the effects of omission of macronutrients on the growth and nutritional status of basil cultivated in nutritive solution.

\section{Materials and methods}

An experiment with basil (Ocinum basilicum L.) of the alfavaca variety was carried out in greenhouse conditions at the Faculdade de Ciências Agrárias e Veterinárias of the UNESP in Jaboticabal County, Sao Paulo State, Brazil. The plants were cultivated in $2.6 \mathrm{~L}$ plant pots.

Seven treatments consisting of nutritive solutions with either nitrogen, phosphorus, potassium, calcium, magnesium and sulfur ( $\mathrm{N}, \mathrm{P}, \mathrm{K}, \mathrm{Ca}, \mathrm{Mg}, \mathrm{S})$ omitted and a complete solution treatment were evaluated in a completely randomized design with three replicates. For the duration of the experiment, the pots were moved around inside the greenhouse viewing area to expose the plants to a uniform condition of luminosity, humidity, and temperature.

The experiment was installed in the greenhouse starting with 20 day old basil seedlings transplanted to pots (one seedling per $2.6 \mathrm{~L}$ pot) containing Hoagland and Arnon (1950) solution diluted, in the first week, to $50 \%$ of its usual concentration and then, starting in the second week until the end of the experiment, at its usual concentration and with the omission of macronutrients.

The nutritive solutions were prepared with deionized water and replaced each 15 days. The $\mathrm{pH}$ was adjusted to $5.5 \pm 0.5$. Deionized water was used to replace evapotranspirated water, with the nutritive solution being constantly oxygenated with the help of an air compressor connected to hoses pumping air into the pots.

The plants were harvested 56 days after transplantation (DAT). At that time, plant height (from the plant lap up to the apex of the last developed leaf), the total number of leaves per plant, an indirect measure of chlorophyll content from reading the relative chlorophyll index (RCI) in ten leaves per experimental unit using a Chlorophyll Content Meter from OPTI-Sciences ${ }^{\circledR}$ model CCM-200 (OptiSciences, Tyngsboro, MA, USA), (Richardson et al., 2002), the leaf area with an LI-3100 Area Meter (LI-COR Inc., Lincoln, NE, USA) (Posse et al., 2009), the rate of net photosynthesis, and stomata conductance in two leaves per experimental unit using an open system portable infrared gas analyser (IRGA) model LICOR 6400. The measurements were made between 8 am and 3 pm in totally extended leaves under good phytosanitary conditions. The responses of the photosynthetic variables to the luminosity intensity were determined for a density of photon flux (PPFD) of $550 \mu \mathrm{mol} \mathrm{m}^{-2} \mathrm{~s}^{-1}$ with the foliar chamber adjusted to operate with a carbon dioxide $\left(\mathrm{CO}_{2}\right)$ concentration of $380 \pm 5 \mu \mathrm{mol} \mathrm{mol}^{-1}$, temperature of $31 \pm 1^{\circ} \mathrm{C}$ and water vapor of $21 \pm 1 \mathrm{mmol} \mathrm{mol}^{-1}$ with leaf area of $1 \mathrm{~cm}^{2}$.

The harvested plant material was washed with deionized water, divided into its aerial and root parts, and then placed in an oven with forced ventilation at $65^{\circ} \mathrm{C}$ until a constant weight was achieved. This material was used to determine the dry matter weight and the macronutrient content, making use of analytical procedures described by Bataglia et al. (1983).

During the experimental period, starting from the first week in which the nutrient solution had $100 \%$ of its full composition, any visual symptoms characteristic of each missing nutrient were described daily.

The experimental data were submitted to analysis of variance and the $\mathrm{F}$ values were calculated. The means compared by Tukey's test $\mathrm{P}=0.05$ with the help of AgroEstat (Barbosa and Maldonado, 2012) software.

\section{Results and discussion}

The effects of the treatments on the studied variables as well as eventual nutritional disorders due to macronutrient omission are discussed for each nutrient.

\section{Nitrogen deficiency}

Nitrogen omission suppressed vegetative development, affecting the height, number of leaves, leaf area, relative chlorophyll index, rate of net photosynthesis and stomata conductance (Table 1). Thereafter, 
Table 1. Height, number of leaves, leaf area, relative chlorophyll index ( $\mathrm{RCl})$, stomatal conductance and net photosynthesis rate in aerial part and roots of basil plants.

\begin{tabular}{|c|c|c|c|c|c|c|}
\hline \multirow{2}{*}{ Treatment } & \multirow{2}{*}{$\begin{array}{l}\text { Height } \\
\mathrm{cm}\end{array}$} & \multirow{2}{*}{ Number of leaves } & \multirow{2}{*}{$\begin{array}{l}\text { Leaf area } \\
\mathrm{mm}^{2}\end{array}$} & \multirow[b]{2}{*}{$\mathrm{RCl}$} & \multirow{2}{*}{\multicolumn{2}{|c|}{$\begin{array}{l}\text { Stomatal conductance } \quad \text { Net photosynthesis rate } \\
\text { - }\end{array}$}} \\
\hline & & & & & & \\
\hline Complete solution & $64.6 \mathrm{a}$ & $157.3 \mathrm{a}$ & 6398.7 a & $21.4 \mathrm{a}$ & $1.34 \mathrm{a}$ & $51.2 \mathrm{a}$ \\
\hline$-\mathrm{N}$ & $10.2 \mathrm{e}$ & $9.0 \mathrm{e}$ & $99.8 \mathrm{e}$ & $4.7 \mathrm{e}$ & $0.65 c$ & $2.6 \mathrm{e}$ \\
\hline$-P$ & $62.1 \mathrm{a}$ & $87.3 \mathrm{c}$ & $1631.1 \mathrm{~b}$ & $18.3 \mathrm{~b}$ & $0.96 \mathrm{~b}$ & $25.2 \mathrm{~cd}$ \\
\hline$-K$ & $37.1 \mathrm{c}$ & $110.3 b$ & $1402.4 \mathrm{bc}$ & $8.8 \mathrm{~d}$ & $0.94 \mathrm{~b}$ & $37.7 \mathrm{~b}$ \\
\hline$-\mathrm{Ca}$ & $10.0 \mathrm{e}$ & $15.3 \mathrm{e}$ & $25.6 \mathrm{e}$ & $13.7 \mathrm{c}$ & $0.10 d$ & $15.8 \mathrm{~d}$ \\
\hline$-\mathrm{Mg}$ & $29.8 d$ & $69.0 \mathrm{~d}$ & $796.9 \mathrm{~d}$ & $5.3 \mathrm{e}$ & $0.90 \mathrm{bc}$ & $29.3 b c$ \\
\hline$-S$ & $46.3 \mathrm{~b}$ & $93.3 \mathrm{c}$ & $1155.1 \mathrm{~cd}$ & $8.6 \mathrm{~d}$ & $0.17 d$ & $28.3 \mathrm{bc}$ \\
\hline F test & $50.7^{* *}$ & $84.1^{* *}$ & $12.7^{* *}$ & $27.7^{* *}$ & $3.0^{*}$ & $6.8^{* *}$ \\
\hline
\end{tabular}

**and ${ }^{*}$-Significant at 1 and $5 \%$ levels.

there was a suppression in aerial dry matter yield as reported by Yermiyahu et al. (2006), Souza et al. (2007) and Nurzynska-Weirdak et al. (2011) as well as in root dry matter yield, compared to the control treatment (Table 2). The beneficial effects of $\mathrm{N}$ on height, yield and leaf area (Tesi et al., 1995) as well as chloroplast quantity (Politycka and Golcz, 2004) have been noted previously by others.

When comparing the $\mathrm{N}$ omission treatment with the control (complete nutritive solution) there was a decrease in the aerial macronutrient content, except for $\mathrm{Mg}$, which retained the same level (Table 3). The $\mathrm{N}$ content in the roots was evaluated and found to be 39.0 and $10.4 \mathrm{~g} \mathrm{~kg}^{-1}$ in the control and $\mathrm{N}$ omitted formulations, respectively. Regarding the other nutrients, $\mathrm{Mg}$ and S presented lower contents in the $\mathrm{N}$ omission treatment, the opposite of what occurred with $\mathrm{P}, \mathrm{K}$, and $\mathrm{Ca}$.

Nitrogen omission, besides leading to a smaller accumulation of $\mathrm{N}$, also affected the other nutrients (Table 4). These effects occurred principally due to a smaller dry matter yield in the suppressed $\mathrm{N}$ plants.

Due to the direct effects of nitrogen omission on the growth of basil and nutrition, deficiency symptoms were observed immediately, commencing the first week of cultivation. It was noted that reduced vegetative development of the aerial parts and root system, and yellowing of older leaves that implied premature senescence and consequently led to plant death.

According to Souza and Fernandes (2006), N is an essential component of proteins, nucleic acids and many other important cellular constituents, including membranes and various hormones. This nutrient deficiency results in a gradual chlorosis and growth restriction.

\section{Phosphorus deficiency}

Development variables were influenced by omission of $P$ from the nutritional solution compared to the control treatment. Thus the beneficial effect of phosphorus on plant growth was strongly evident, a fact

Table 2. Dry matter production of basil plants (dry weight).

\begin{tabular}{|c|c|c|c|}
\hline \multirow[b]{3}{*}{ Treatment } & \multicolumn{3}{|c|}{ Dry matter } \\
\hline & Aerial part & Roots & Whole plant \\
\hline & & g per plar & -- \\
\hline Complete solution & $16.9 \mathrm{a}$ & $6.1 \mathrm{a}$ & $23.0 \mathrm{a}$ \\
\hline$-\mathrm{N}$ & $0.4 \mathrm{e}$ & $0.5 \mathrm{c}$ & $0.9 c$ \\
\hline$-P$ & $4.9 \mathrm{~b}$ & $3.2 \mathrm{~b}$ & $8.1 \mathrm{~b}$ \\
\hline$-K$ & $4.5 \mathrm{bc}$ & $2.4 \mathrm{~b}$ & $6.9 \mathrm{~b}$ \\
\hline$-\mathrm{Ca}$ & $0.5 \mathrm{e}$ & $0.5 \mathrm{c}$ & $1.0 \mathrm{C}$ \\
\hline$-\mathrm{Mg}$ & $1.3 \mathrm{de}$ & $0.8 c$ & $2.1 \mathrm{c}$ \\
\hline$-S$ & $3.0 \mathrm{~cd}$ & $3.0 \mathrm{~b}$ & $6.0 \mathrm{~b}$ \\
\hline F test & $8.8^{* *}$ & $19.4^{* *}$ & $13.9^{* *}$ \\
\hline
\end{tabular}

**and ${ }^{*}$-Significant at 1 and $5 \%$ levels. 
Table 3. Macronutrient concentration in aerial part and roots of basil plants.

\begin{tabular}{|c|c|c|c|c|c|c|}
\hline Treatment & $\mathrm{N}$ & $P$ & K & $\mathrm{Ca}$ & $\mathrm{Mg}$ & $S$ \\
\hline & \multicolumn{5}{|c|}{ - - - - - - - - $-\mathrm{g} \mathrm{kg}^{-1}$} & \\
\hline & \multicolumn{6}{|c|}{ Aerial part } \\
\hline Complete solution & $30.2 \mathrm{a}$ & $7.4 \mathrm{ab}$ & $42.8 \mathrm{a}$ & $12.9 \mathrm{~b}$ & $5.2 \mathrm{~b}$ & $2.8 \mathrm{a}$ \\
\hline$-\mathrm{N}$ & $7.6 \mathrm{c}$ & $2.5 \mathrm{~d}$ & $19.3 \mathrm{c}$ & $9.4 \mathrm{c}$ & $4.7 \mathrm{~b}$ & $1.2 \mathrm{~d}$ \\
\hline$-P$ & $24.3 \mathrm{~b}$ & 0.7 e & $30.4 \mathrm{~b}$ & $10.2 \mathrm{c}$ & $2.2 \mathrm{~d}$ & $1.5 \mathrm{~cd}$ \\
\hline$-K$ & $35.3 \mathrm{a}$ & $6.4 b c$ & $6.9 \mathrm{~d}$ & $16.1 \mathrm{a}$ & $4.9 \mathrm{~b}$ & $1.9 \mathrm{bc}$ \\
\hline$-\mathrm{Ca}$ & $32.0 \mathrm{a}$ & $8.5 \mathrm{a}$ & $41.8 \mathrm{a}$ & $4.2 \mathrm{~d}$ & $7.1 \mathrm{a}$ & $2.4 a b$ \\
\hline$-M g$ & $32.8 \mathrm{a}$ & $7.7 \mathrm{ab}$ & 45.8 a & $14.8 \mathrm{ab}$ & $0.7 \mathrm{e}$ & $2.3 \mathrm{ab}$ \\
\hline$-S$ & 31.5 & $5.6 \mathrm{c}$ & $32.1 \mathrm{~b}$ & $16.3 \mathrm{a}$ & $3.2 \mathrm{c}$ & $1.0 \mathrm{~d}$ \\
\hline \multirow[t]{2}{*}{ F test } & $25.0^{* *}$ & $157.1^{* *}$ & $141.3^{* *}$ & $56.3^{* *}$ & $43.2^{* *}$ & $17.5^{* *}$ \\
\hline & \multicolumn{6}{|c|}{ Roots } \\
\hline Complete solution & $39.0 \mathrm{a}$ & $4.6 \mathrm{C}$ & $16.8 \mathrm{e}$ & $4.3 \mathrm{c}$ & $6.9 \mathrm{a}$ & $3.9 \mathrm{~b}$ \\
\hline$-\mathrm{N}$ & $10.4 \mathrm{e}$ & $7.3 \mathrm{a}$ & $50.5 \mathrm{a}$ & $7.2 \mathrm{ab}$ & $5.5 \mathrm{~b}$ & $2.9 \mathrm{~d}$ \\
\hline$-P$ & $31.5 \mathrm{bc}$ & $1.6 \mathrm{~d}$ & $41.6 \mathrm{~b}$ & $7,3 a b$ & $3.1 \mathrm{c}$ & $3.5 \mathrm{bc}$ \\
\hline$-K$ & $35.5 a b$ & $7.3 \mathrm{a}$ & $3.9 \mathrm{f}$ & $7.8 \mathrm{a}$ & $5.2 \mathrm{~b}$ & $5.1 \mathrm{a}$ \\
\hline$-\mathrm{Ca}$ & $25.3 d$ & $2.4 \mathrm{~d}$ & $3.1 \mathrm{f}$ & $1.9 \mathrm{~d}$ & $7.3 \mathrm{a}$ & $2.9 \mathrm{~cd}$ \\
\hline$-M g$ & $27.4 \mathrm{~cd}$ & $4.8 \mathrm{bc}$ & $31.6 \mathrm{~d}$ & $8.1 \mathrm{a}$ & $1.3 \mathrm{~d}$ & $3.9 \mathrm{~b}$ \\
\hline$-S$ & $31.6 b c$ & $6.3 \mathrm{ab}$ & $35.7 c$ & $5.6 \mathrm{bc}$ & $3.0 c$ & $1.2 \mathrm{e}$ \\
\hline F test & $36.6^{* *}$ & $40.0^{* *}$ & $183.1^{* *}$ & $13.3^{* *}$ & $79.2^{* *}$ & $48.4^{* *}$ \\
\hline
\end{tabular}

**and *-Significant at 1 and $5 \%$ levels.

also observed by Ichimura et al. (1995) in basil plants. The absence of $\mathrm{P}$ in the nutritive solution mainly affected net plant photosynthesis, because there was a decrease in ICR.

Facing with this lack of $\mathrm{P}$ during plant development, there was a limitation in the dry matter yield of leaves and roots compared with plants that received the complete nutrient solution (Table 2). Similar results were found by Souza et al. (2007), where a lack of $\mathrm{P}$ affected the development of mint. However,

Table 4. Macronutrient accumulation in aerial part and roots of basil plants.

\begin{tabular}{|c|c|c|c|c|c|c|}
\hline Treatment & $\mathrm{N}$ & $P$ & K & $\mathrm{Ca}$ & $\mathrm{Mg}$ & $S$ \\
\hline & \multicolumn{6}{|c|}{--mg per plant-_-二_-_-_-_- } \\
\hline & \multicolumn{6}{|c|}{ Aerial part } \\
\hline Complete solution & $510.1 \mathrm{a}$ & 124.7 a & $725.1 \mathrm{a}$ & $219.2 \mathrm{a}$ & 87.5 a & $48.2 \mathrm{a}$ \\
\hline$-\mathrm{N}$ & $2.7 \mathrm{~d}$ & $0.9 \mathrm{~d}$ & $7.1 \mathrm{c}$ & $3.4 \mathrm{c}$ & $1.7 \mathrm{c}$ & $0.4 \mathrm{~b}$ \\
\hline$-P$ & $118.9 \mathrm{~b}$ & $3.3 \mathrm{~cd}$ & $149.1 \mathrm{~b}$ & $50.2 \mathrm{~b}$ & $10.7 c$ & $7.3 \mathrm{~b}$ \\
\hline$-K$ & $158.8 \mathrm{~b}$ & $28.8 \mathrm{~b}$ & $30.9 c$ & $71.9 \mathrm{~b}$ & $21.7 b$ & $8.8 \mathrm{~b}$ \\
\hline$-\mathrm{Ca}$ & $14.8 d$ & $3.9 \mathrm{~cd}$ & $19.3 \mathrm{c}$ & $1.9 \mathrm{c}$ & $3.3 c$ & $1.1 \mathrm{~b}$ \\
\hline$-\mathrm{Mg}$ & $42.7 \mathrm{~cd}$ & $10.1 \mathrm{~cd}$ & $59.1 b c$ & $19.3 \mathrm{c}$ & $0.9 \mathrm{~d}$ & $3.0 \mathrm{~b}$ \\
\hline \multirow[t]{3}{*}{$-S$} & $95.3 \mathrm{bc}$ & 16.9 bc & $97.5 \mathrm{bc}$ & $49.6 \mathrm{~b}$ & $9.7 c$ & $3.0 \mathrm{~b}$ \\
\hline & $7.9^{* *}$ & $14.0^{* *}$ & $17.4^{* *}$ & $7.4^{* *}$ & $21.0^{* *}$ & $25.2^{* *}$ \\
\hline & \multicolumn{6}{|c|}{ Roots } \\
\hline Complete solution & $239.1 \mathrm{a}$ & $28.3 \mathrm{a}$ & $103.2 \mathrm{a}$ & $26.1 \mathrm{a}$ & $41.9 \mathrm{a}$ & $23.6 \mathrm{a}$ \\
\hline$-\mathrm{N}$ & $5.5 \mathrm{c}$ & $3.9 c$ & $26.9 \mathrm{~b}$ & $3.8 \mathrm{c}$ & $2.9 \mathrm{c}$ & $1.5 \mathrm{c}$ \\
\hline$-P$ & $100.7 \mathrm{~b}$ & $5.3 c$ & $132.8 \mathrm{a}$ & $23.9 \mathrm{a}$ & $10.1 \mathrm{~b}$ & $11.5 \mathrm{~b}$ \\
\hline$-K$ & $86.8 \mathrm{~b}$ & $17.9 \mathrm{~b}$ & $9.7 \mathrm{~b}$ & $18.9 \mathrm{ab}$ & $12.8 \mathrm{~b}$ & 12. $4 \mathrm{~b}$ \\
\hline$-\mathrm{Ca}$ & $13.4 \mathrm{c}$ & $1.2 \mathrm{c}$ & $1.6 \mathrm{~b}$ & $1.0 \mathrm{c}$ & $3.8 \mathrm{c}$ & $1.6 \mathrm{C}$ \\
\hline$-\mathrm{Mg}$ & $20.8 c$ & $3.6 \mathrm{C}$ & $24.0 \mathrm{~b}$ & $6.1 \mathrm{bc}$ & $1.0 \mathrm{C}$ & $3.0 \mathrm{c}$ \\
\hline \multirow[t]{3}{*}{$-S$} & $95.8 \mathrm{~b}$ & $19.1 \mathrm{~b}$ & $107.2 \mathrm{a}$ & $17.1 \mathrm{ab}$ & $8.9 \mathrm{~b}$ & $3.2 \mathrm{c}$ \\
\hline & $15.7^{* *}$ & $15.6^{* *}$ & $14.6^{* *}$ & $6.1^{* *}$ & $39.6^{* *}$ & $15.3^{* *}$ \\
\hline & \multicolumn{6}{|c|}{ Whole plant } \\
\hline Complete solution & $749.3 \mathrm{a}$ & $153.1 \mathrm{a}$ & $828.3 \mathrm{a}$ & $245.3 \mathrm{a}$ & $129.3 \mathrm{a}$ & $71.7 \mathrm{a}$ \\
\hline$-\mathrm{N}$ & $8.3 \mathrm{c}$ & $4.8 \mathrm{c}$ & $34.0 \mathrm{c}$ & $7.2 \mathrm{c}$ & $4.6 \mathrm{~d}$ & $1.9 \mathrm{c}$ \\
\hline$-P$ & $219.7 b$ & $8.6 \mathrm{C}$ & $281.9 \mathrm{~b}$ & $74.1 \mathrm{~b}$ & $20.8 c$ & $18.8 \mathrm{~b}$ \\
\hline$-K$ & $245.6 \mathrm{~b}$ & $46.7 \mathrm{~b}$ & $40.6 c$ & $90.9 \mathrm{~b}$ & $34.4 \mathrm{~b}$ & $21.3 \mathrm{~b}$ \\
\hline$-\mathrm{Ca}$ & $28.2 \mathrm{c}$ & $5.2 \mathrm{c}$ & $20.9 c$ & $2.9 \mathrm{c}$ & $7.1 \mathrm{~d}$ & $2.6 \mathrm{C}$ \\
\hline$-M g$ & $63.5 c$ & $13.7 \mathrm{c}$ & $83.1 \mathrm{c}$ & $25.5 \mathrm{c}$ & $1.8 \mathrm{~d}$ & $6.0 c$ \\
\hline$-S$ & $191.2 b$ & $35.9 \mathrm{~b}$ & 204.7 b & $66.6 \mathrm{~b}$ & $18.6 \mathrm{c}$ & $6.5 c$ \\
\hline F test & $13.6^{* *}$ & $19.0^{* *}$ & $19.7^{* *}$ & $8.2^{* *}$ & $42.8^{* *}$ & $31.1^{* *}$ \\
\hline
\end{tabular}

**and ${ }^{*}$-Significant at 1 and $5 \%$ levels. 
it is important to note that excessive increases in nutrients can generate a higher production, but can also promote a decrease in oil quality (Sharafzadeh et al., 2011).

The plants that received the treatment without $\mathrm{P}$ showed a drastic reduction in nutrient content in the aerial part $\left(0.7 \mathrm{~g} \mathrm{~kg}^{-1}\right)$, achieving only one-tenth the value when compared to the complete treatment $\left(7.4 \mathrm{~g} \mathrm{~kg}^{-1}\right)$. This decrease also was seen in the root system, $1.6 \mathrm{~g} \mathrm{~kg}^{-1}$ in the omission treatment, versus $4.6 \mathrm{~g} \mathrm{~kg}^{-1}$ in the full treatment.

Higher accumulation rates were found for the majority of the treatments in the aerial part and root system, but not in the case of $\mathrm{K}$ and $\mathrm{Ca}$, where their accumulations in the $\mathrm{P}$ omission treatment were equal to those with complete treatment (Table 4).

Phosphorus deficiency symptoms were characterized by darker green leaves and limited plant development. The roots were also thinner and longer than the complete solution treatment, although these symptoms were not visible until the 63rd day. That observation was probably due to the high $\mathrm{P}$ reserve of the plant and its low $\mathrm{P}$ necessity, thus postponing the appearance of symptoms.

\section{Potassium deficiency}

Omission of $\mathrm{K}$ restricted plant growth (Table 1) as described in Nurzynska-Weirdak et al. (2011). As a result of the deficiency, there was a decreased dry matter yield in the plants (Table 2), with the aerial part providing a yield only $25 \%$ of the full treatment.

As mentioned by Araujo et al. (2011), omission of potassium in plants led to consequent effects that harmed the relative chlorophyll index, since $\mathrm{K}$ is necessary for chlorophyll development (Passos, 1999). It could also lead to a decrease in quality of the essential oil present in the plant (Sharafzadeh et al., 2011).

The plants subjected to $\mathrm{K}$ omission showed a reduced content of $\mathrm{K}$ in the aerial part $\left(6.9 \mathrm{~g} \mathrm{~kg}^{-1}\right)$ and root system $\left(3.9 \mathrm{~g} \mathrm{~kg}^{-1}\right)$ compared to the complete treatment $\left(42.8\right.$ and $16.8 \mathrm{~g} \mathrm{~kg}^{-1}$, aerial part and root system, respectively) (Table 3), and close to those found by Nguyen et al. (2010). The same result occurred with potassium accumulation, which was higher with the control treatment (828 g per plant), compared to the K-deficient (41 mg per plant) (Table 4). When it was evaluated, the content of other nutrients it was noticed that $\mathrm{N}, \mathrm{P}$, and $\mathrm{Mg}$ all presented with similar contents to those found with the complete treatment.

Due to impediments on plant development, the lack of $K$ provided characteristic visual symptoms on the plants, such as chlorosis on borders of old leaves followed by the appearing of freckles in the central part of leaves and eventually necrosis, then extending to the middle-aged leaves. Presumably the effects appeared primarily on old leaves because of nutrient mobility in the plant, being translocated to growth areas (Marschner, 1995).

\section{Calcium deficiency}

Calcium omission significantly limited plant development, affecting all variables (Table 1). With this deficiency, there was a significant decrease in plant dry matter yield compared to the full treatment (Table 2), as previously reported by Yermiyahu et al. (2006). According to Dzida (2010), once the amount of Ca necessary for complete plant development is reached, further increases in Ca do not increase production, whereas Ca-deficient plants do not have this crucial amount necessary to complete their life cycle.

It was noted that plants subjected to $\mathrm{Ca}$ omission presented a smaller nutrient content in the aerial part $\left(4.2 \mathrm{~g} \mathrm{~kg}^{-1}\right)$ than the ones submitted to the control treatment $\left(12.9 \mathrm{~g} \mathrm{~kg}^{-1}\right)$; this result also was noted in the root system (1.9 versus $4.3 \mathrm{~g} \mathrm{~kg}^{-1}$, respectively) (Table 3 ). The same effect was recorded concerning $\mathrm{Ca}$ accumulation by the plants (Table 4 ), which had a very high accumulation with the full treatment (254 mg per plant) almost 100 times greater compared to the deficiency treatment (2.9 $\mathrm{mg}$ per plant).

Regarding the deficiency symptoms of plants that did not receive calcium, their symptoms appeared even before those of the $\mathrm{N}$-deprived ones The initial symptom was necrosis of growth gems and edges 
of young leaves, leading to total death of the plant in a short period of time. The roots were not developed and became dark brown, also due to necrosis.

\section{Magnesium deficiency}

Magnesium deficiency also affected plant growth and development, affecting all studied variables (Table 1). Because this nutrient is the central molecule in chlorophyll (Marschner, 1995), its absence harms photosynthesis. There was a decrease in dry matter production (Table 2) in the aerial part just as in the root system, also verified by Mikiciuk et al. (2008).

Plants suffering from $\mathrm{Mg}$ omission showed lower nutrient content in the aerial part $\left(0.7 \mathrm{~g} \mathrm{mg}^{-1}\right)$ and root system $\left(1.3 \mathrm{~g} \mathrm{~kg}^{-1}\right)$ than the full treatment (5.2 and $6.9 \mathrm{~g} \mathrm{~kg}^{-1}$, respectively) (Table 3). The same result occurred with $\mathrm{Mg}$ accumulation in the plants, with a very high accumulation under the full treatment (129 mg per plant) compared to Mg-deficient plants (1.8 mg per plant) (Table 4).

The effect of $\mathrm{Mg}$ omission restricted the development of the culture sufficiently so that visual symptoms of deficiency appeared, including internerval chlorosis from the edge of the leaves to the central part, followed by curling and tissue necrosis, initially appearing in older leaves.

\section{Sulfur deficiency}

Sulfur omission promoted a restriction on vegetative development (Table 1), thereby causing the production of dry matter, as described in Zheljazkov et al. (2008), to be compromised (Table 2).

Plants suffering from $S$ omission showed lower levels of $S$ in the aerial part $\left(1.0 \mathrm{~g} \mathrm{~kg}^{-1}\right)$ and roots $\left(1.2 \mathrm{~g} \mathrm{~kg}^{-1}\right)$ than the complete treatment $\left(2.8 \mathrm{~kg}\right.$ and $\left.3.9 \mathrm{~g}^{-1}\right)$ (Table 3$)$. The same result occurred with $\mathrm{S}$ accumulation in the plants, with a higher accumulation in the complete treatment $(71.7 \mathrm{mg}$ per plant) compared to the $S$ deficiency treatment (6.5 mg per plant) (Table 4 ).

Nutritional disorders also were observed in aerial parts of the plant. Basil is apparently also a very demanding plant for $\mathrm{S}$, since deficiency symptoms appeared when the plants was young, and they were very characteristic. The primary symptom was the central yellowing of young leaves (Marschner, 1995) of the plant.

\section{Conclusions}

Nutrient omission was limiting for plant development, substantially restricting vegetative growth and yield. There was also a considerable suppression in nutrient accumulation compared to the control treatment. Visual symptoms of deficiency were observed with all treatments with omissions of nutrients.

\section{References}

Araujo, G. S., S. N. Matsumoto, M. A. F. Santos, F. R. C. F. Cesar, and J. A. Bonfim. 2011. Sweet basil growth under protected cultivation conditioned to nitrogen doses and supraoptimal potassium doses. Ambiencia 7: 265-277.

Barbosa, J. C., and W. Maldonado Jr. 2012. AgroEstat - Statistical system of agronomic trials analysis, Version 1.0. Jaboticabal, Brazil: UNESP.

Bataglia, O. C., A. M. C. Furlani, J. P. F. Teixeira, P. R. Furlani, and J. R. Gallo. 1983. Methods of Chemical Analysis of Plant. Campinas, Brazil: Instituto Agronômico.

Blank, A. F., J. L. S. Carvalho Filho, A. L. Santos Neto, P. B. Alves, M. F. Arri Goni-Blank, R. Silva-Mann, and M. C. Mendonça. 2004. Morphologic and agronomic characterization of basil accessions. Horticultura Brasileira 22: 113116.

Dzida, K. 2010. Biological value and essential oil content in sweet basil (Ocimum basilicum L.) depending on calcium fertilization and cultivar. Acta Scientarum Polonorum, Hortorum Cultus 9: 153-161.

Dzida, K. 2011. Influence of nitrogen nutrition and cultivar on quality of sweet basil herbs. Anals Universitatis Mariae Curie-Sklodowska, Lublin - Polonia 24: 125-132.

Hoagland, D. R., and D. I. Arnon. 1950. The water culture method for growing plants without soils. Berkeley, CA: California Agricultural Experimental Station. 
Ichimura, M., M. Ikushima, T. Miyazaki, and M. Kimura. 1995. Effect of phosphorus on growth and concentration of mineral elements and essential oils of sweet basil leaves. Acta Horticulturae 396: 195-202.

Marschner, H. 1995. Mineral Nutrition of Higher Plants. Amsterdam: Academic Press.

Mikiciuk, M., K. Malinowska, and J. Wróbel. 2008. Effects of magnesium nutrition under varying soil moisture conditions on some physiological features of fragrant basil (Ocimum basilicum L.). Ecological Chemistry and Engineering 15: 93102.

Nguyen, P. M., E. M. Kwee, and E. D. Niemeyer. 2010. Potassium rate alters the antioxidant capacity and phenolic concentration of basil (Ocimum basilicum L.) leaves. Food Chemistry 123: 1235-1241.

Nurzynska-Weirdak, R., E. Rozek, and B. Borowski. 2011. Response of different basil cultivars to nitrogen and potassium fertilization: Total and mineral nitrogen content in herb. Acta Scientarum Polonorum, Hortorum Cultus 10: $217-232$.

Passos, L. P. 1999. Physiology of elephant grass: An analytical review. In: Biology and Management of Elephant Grass, eds. L. P. Passos, L. A. Carvalho and C. E. Martins, vol. 1, pp. 29-62. Juiz de Fora, Brazil: Embrapa Gado de Leite.

Pereira, R. C. A., and A. L. M. Moreira. 2011. Basil: Cultivation and Utilization. Brasília, Brazil: EMBRAPA.

Politycka, B., and A. Golcz. 2004. Content of chloroplast pigments and anthocyanins in the leaves of Ocimum basilicum L. depending on nitrogen doses. Folia Horticulturae 16: 23-29.

Posse, R. P., E. F. de Sousa, S. Bernardo, M. G. Pereira, and R. D. Gottardo. 2009. Total leaf area of papaya trees estimated by a nondestructive method. Scientia Agricola 66: 462-466.

Richardson, A. D., S. P. Duigan, and G. P. Berlyn. 2002. An evaluation of noninvasive methods to estimate foliar chlorophyll content. New Phytologist 153: 185-194.

Sharafzadeh, S., M. Esmaeili, and A. H. Mohammadi. 2011. Interaction effects of nitrogen, phosphorus and potassium on growth, essential oil and total phenolic content of sweet basil. Advances in Environmental Biology 5: 1285-1289.

Souza, M. A. A., O. J. L. Araújo, M. A. Ferreira, E. M. L. M. Stark, M. S. Fernandes, and S. R. Souza. 2007. Biomass and essential oil production of mint in hydroponic system as a function of nitrogen and phosphorus. Horticultura Brasileira 25: 41-48.

Souza, S. R., and M. S. Fernandes. 2006. Nitrogen. Mineral Plant Nutrition 1: 215-252.

Tesi, R., G. Chisci, A. Nencini, and R. Tallarico. 1995. Growth response to pertilisationof sweet basil (Ocimum basilicum L.). Acta Horticulturae 390: 93-96.

Yermiyahu, U., I. Shamai, R. Peleg, N. Dudai, and D. Shtienberg. 2006. Reduction of Botrytis cinerea sporulation in sweet basil by altering the concentrations of nitrogen and calcium in the irrigation solution. Plant Pathology 55: 544-552.

Zheljazkov, V. D., C. L. Cantrell, M. W. Ebelhar, D. E. Rowe, and C. Coker. 2008. Productivity, oil content, and oil composition of sweet basil as a function of nitrogen and sulfur fertilization. HortScience 43: 1415-1422. 